\title{
EFFECTS OF PRUNING IN THE MANAGEMENT OF DOGWOOD AND PINE BRANCH DIEBACK IN THE LANDSCAPE
}

\author{
by Gary W. Moorman and Roxanne J. Lease
}

\begin{abstract}
Scots pines (Pinus sylvestris L.) at 2 locations and dogwoods (Cornus florida L.) at 1 location were observed for branch dieback from spring 1996 through autumn 1998. Some trees at each location were comprehensively pruned to eliminate dead twigs and branches and compared to trees not pruned. Of the branch-killing fungi present, Sphaeropsis was the most important in the pines, and Discula and Botryosphaeria were the prominent ones in the dogwoods. We concluded that comprehensive pruning of branches killed by fungi significantly improves the appearance of Scots pines and dogwoods but does not totally eliminate disease from the trees.
\end{abstract}

Key Words. Scots pine; Pinus sylvestris; dogwood; Cornus florida; cankers; disease; pruning.

Sphaeropsis tip blight in Scots pines (Pinus sylvestris L.) (Stahl 1968; Bega et al. 1978; Blodgett and Stanoz 1995; Stanoz et al. 1997) and the branch dieback associated with dogwood (Cornus florida L.) anthracnose (Discula destructiva Redlin) (Anderson et al. 1994; Gould and Peterson 1994) and Botryosphaeria canker are among the most prevalent and destructive diseases affecting the health and aesthetic quality of these important landscape trees in the northeastern United States. These trees require special attention in the landscape and have earned their designation as "key plants" in Integrated Pest Management strategies (Moorman 1984; Raupp et al. 1985). These and other branch-killing diseases are difficult to prevent in the landscape. The fungi involved can be natural inhabitants on the plants' bark, gaining entry to the plant through wounds or natural openings at any time of the year. Many canker-causing fungi remain latent in the infected tissue until plant resistance responses are suppressed during dormancy or reduced by environmental stress (Schoeneweiss 1975, 1981; Blodgett and Stanoz 1995; Stanoz et al. 1997). In most cases, it is not physically or economically feasible or environmentally desirable to maintain an effective level of fungicide on the trees in order to prevent infection. By the time symptoms are noticed, the cankering and branch-killing fungi have been active for some time and have colonized tissues inaccessible to chemical treatment. Further, the presence of dead branches reduces the aesthetic quality of trees and forces owners to remove and replace the trees.

Although the standard management recommendation for these diseases is to prune the infected branches, the effectiveness of this approach has not been established. Even after removing symptomatic plant tissue and thereby removing some of the pathogen, it is not known how much asymptomatic, infected tissue remains in the plant only to manifest itself at a later date. The purpose of this research was to determine whether comprehensively pruning infected branches results in a significant improvement in Scots pine and dogwood health and aesthetic quality in the landscape.

\section{MATERIALS AND METHODS}

In 1996, 2 plots of Scots pines in Centre County, Pennsylvania, were located: Plot \#1 consisted of a single row of 14-year-old pines, averaging $8.4 \mathrm{~m}(27.7 \mathrm{ft})$ tall and at least $1.6 \mathrm{~m}(5.3 \mathrm{ft})$ apart. These trees were situated along the edge of a golf course rough and their branches formed a closed lower crown. Most of the vegetation among the trees was tall grasses. Two blocks of trees with approximately the same incidence and severity of branch dieback, primarily Sphaeropsis tip dieback (Sphaeropsis sapinae (Fr.) Dyko \& Sutton = Diplodia pinea (Desm.) Kickx.), were selected. Six control trees were not pruned, while 10 trees were pruned to remove as many dead twigs and branches as feasible. Plot $\# 2$ originally consisted 12 rows of 8 Scots pines planted on a 1.6-m spacing. The plot was modified by removing every other tree in a staggered pattern to increase spacing. All dead, damaged, and severely distorted trees were also removed. The trees were approximately 11 years old and averaged $3.7 \mathrm{~m}$ $(12.2 \mathrm{ft})$ tall. The area under the trees was covered 
with fallen needles. Two blocks of trees were established. One block of 23 trees served as the unpruned control, while the second block of 17 trees was pruned. Initially, the blocks contained trees with similar ranges of branch dieback.

A plot of mature dogwoods affected primarily by anthracnose and Botryosphaeria canker (Botryosphaeria spp.) was located at Longwood Gardens, Kennett Square, Pennsylvania The trees, scattered on a hillside, were at least $10 \mathrm{~m}(33 \mathrm{ft})$ apart and were estimated to be 30 to 40 years old. They averaged $5.9 \mathrm{~m}(19.5 \mathrm{ft})$ tall, and the trunks averaged $86.3 \mathrm{~cm}$ (34.5 in.) in circumference measured at a point $30 \mathrm{~cm}$ (12 in.) above the soil. The trees were divided into 2 groups. Five trees were not pruned and served as the control, while 6 trees were pruned. Trees within each treatment had similar ranges of branch dieback.

In spring 1996, the radii of drip lines and the heights and circumferences of all the trees were measured, and the number of dead branches was determined. A dead branch index (dbi) was calculated ( $\mathrm{dbi}=$ $3 \times$ number of primary branches completely dead $+2 \times$ number of primary branches only the ends of which were dead + percentage of secondary branches that were dead) to quantify the visual appearance of the trees. Trees were also rated for overall branch disease severity using the Horsfall-Barratt scale: $1=$ no disease; $2=0$ to $3 \%$ disease; $3=3 \%$ to $6 \% ; 4=6 \%$ to $12 \% ; 5=$ $12 \%$ to $25 \% ; 6=25 \%$ to $50 \% ; 7=50 \%$ to $75 \% ; 8=$ $75 \%$ to $87 \% ; 9=87 \%$ to $94 \% ; 10=94 \%$ to $97 \% ; 11=$ $97 \%$ to $100 \% ; 12=100 \%$ (Horsfall and Barratt 1945 ).

In spring 1997, comprehensive pruning was performed and pruned material was removed from the vicinity of the trees. In 1997 and 1998, all the above measurements and ratings were taken again and further pruning was done. Although Sphaeropsis tip dieback was present in all the pines and anthracnose and Botryosphaeria canker in all the dogwoods, other diseases were also present and contributed to branch death. Because the objective of the experiment was to determine whether pruning significantly improves the general health of trees in a landscape setting, regardless of the cause branch death, no effort was made to determine the cause of branch death in each case. Tukey's Studentized Range test was applied to the data following analysis of variance (SAS 1985).

\section{RESULTS AND DISCUSSION}

Branch disease severity (Table 1) was not significantly reduced by pruning the pines in plot \#1 or the dogwoods. Pruning significantly reduced branch disease severity in pines in plot \#2. Disease pressure was great at Scots pine plot \#l because a second row of large, severely affected pines not in the experiment had branches touching the experimental trees and the air circulation among all the trees was poor. It is likely that inoculum coming from neighboring trees offset the effect of removing inoculum sources from treated trees. Treatments should be continued in order to evaluate the effects of pruning over a longer term.

Pruning infected twigs and branches greatly enhanced the appearance of the pines and dogwoods, as indicated by the significant reduction in the dead branch index, a numerical value devised to quantify the visual effect of the presence of dead twigs and branches (Table 2). The labor involved in the first year's pruning was intensive; several primary branches and the ends of primary branches were removed. Multiple cuts were necessary in order to avoid tearing bark and to ensure that the final cuts were in positions where callusing would occur. Initially, many secondary branches and twigs also had to be removed.

Table 1. Branch disease severity for Scots pines at 2 locations and dogwoods at 1 location during a 2-year study period.

\begin{tabular}{|c|c|c|}
\hline & \multicolumn{2}{|c|}{ Branch disease severity ${ }^{2}$} \\
\hline & 1997 & 1998 \\
\hline \multicolumn{3}{|l|}{ Pine plot \#1 } \\
\hline No treatment & $1.9 a^{y}$ & $2.7 \mathrm{a}$ \\
\hline Pruned & $1.8 \mathrm{a}$ & $3.0 \mathrm{a}$ \\
\hline \multicolumn{3}{|l|}{ Pine plot \#2 } \\
\hline No treatment & $2.2 \mathrm{a}$ & $2.9 \mathrm{a}$ \\
\hline Pruned & $1.6 \mathrm{~b}$ & $2.1 \mathrm{~b}$ \\
\hline \multicolumn{3}{|l|}{ Dogwoods } \\
\hline No treatment & $2.6 \mathrm{a}$ & \\
\hline Pruned & $2.3 \mathrm{a}$ & \\
\hline \multicolumn{3}{|c|}{$\begin{array}{l}\text { }{ }^{2} \text { Trees were rated for overall branch dieback severity using the } \\
\text { Horsfall-Barrett scale: } 1=\text { no disease; } 2=0 \text { to } 3 \% \text { disease; } 3= \\
3 \% \text { to } 6 \% ; 4=6 \% \text { to } 12 \% ; 5=12 \% \text { to } 25 \% ; 6=25 \% \text { to } 50 \% ; 7 \\
=50 \% \text { to } 75 \% ; 8=75 \% \text { to } 87 \% ; 9=87 \% \text { to } 94 \% ; 10=94 \% \text { to } \\
97 \% ; 11=97 \% \text { to } 100 \% ; 12=100 \% \text {. } \\
\text { yNumbers within a column followed by the same letter are not } \\
\text { significantly different using Tukey's Studentized Range (HSD) at } \\
\text { the } P=0.05 \text { level. }\end{array}$} \\
\hline
\end{tabular}


Table 2. Dead branch indices for Scots pines at 2 locations and dogwoods at 1 location during a 2year study period.

\begin{tabular}{lcc}
\hline & \multicolumn{2}{c}{ Dead branch index } \\
\cline { 2 - 3 } & 1997 & 1998 \\
\hline Pine plot \#1 & $56 \mathrm{a}^{\mathrm{y}}$ & $93 \mathrm{a}$ \\
No treatment & $27 \mathrm{~b}$ & $34 \mathrm{~b}$ \\
Pruned & & \\
Pine plot \#2 & $138 \mathrm{a}$ & $163 \mathrm{a}$ \\
No treatment & $1 \mathrm{~b}$ & $2 \mathrm{~b}$ \\
Pruned & & \\
Dogwoods & $32 \mathrm{a}$ & $39 \mathrm{a}$ \\
No treatment & $17 \mathrm{~b}$ & $11 \mathrm{~b}$ \\
Pruned &
\end{tabular}

${ }^{2}$ Dead branch index $=3 \times$ number of primary branches completely dead $+2 \times$ number of primary branches only the ends of that were dead + percentage of secondary branches that were dead.

YNumbers within a column followed by the same letter are not significantly different using Tukey's Studentized Range (HSD) at the $P=0.05$ level.

However, subsequent pruning was rapid, involving small twigs and branches. The improvement in aesthetic appearance justified the time and labor involved in comprehensive pruning.

\section{CONCLUSION}

Based on these experiments, we conclude that pruning significantly improves the appearance of Scots pines and dogwoods affected by branch dieback. However, it may require several years of pruning before overall disease severity is significantly reduced.

\section{LITERATURE CITED}

Anderson, R.L. , J.L. Knighten, M. Windham, K. Langdon, F. Hendrix, and R. Roncadori. 1994. Dogwood anthracnose and its spread south. USDA Forest Service, Southern Region Protection Report R8-PR 26. 10 pp.

Bega, R.J., R.S. Smith, A.P. Martinez, and C.J. Davis. 1978. Severe damage to Pinus radiata and Pinus pinaster by Diplodia pinea and Lophodermium spp. on Molakai and Lunai in Hawaii. Plant Dis. Report. 62:329-311.

Blodgett, J.T., and G.R. Stanoz. 1995. Sphaeropsis sapinea and host water stress in a red pine plantation in central Wisconsin. Phytopathology 85:1044.
Gould, A.B., and J.L. Peterson. 1994. The effect of moisture and sunlight on the severity of dogwood anthracnose in street trees. J. Arboric. 20:75-78.

Horsfall, J.G., and R.W. Barratt. 1945. An improved grading system for measuring diseases. Phytopathology 35:655.

Moorman, G.W. 1984. How nurserymen can plan effective disease control programs. Am. Nurseryman 160:66-71.

Raupp, M.J., J.A. Davidson, J.J. Holmes, and J.L. Hellman. 1985. The concept of key plants in integrated pest management for landscapes. J. Arboric. 11:317-322.

SAS Institute, Inc. 1985. SAS User's Guide: Statistics (5th ed.). SAS Institute, Inc. Cary, NC. 956 pp.

Schoeneweiss, D.F. 1975. A method for controlling plant water potentials for studies on the influence of water stress on disease susceptibility. Can. J. Bot. 53:647-652.

Schoeneweiss, D.F. 1981. The role of environmental stress in diseases of woody plants. Plant Dis. 65:308-314.

Stahl, W. 1968. Diplodia pinea: A preliminary report on some aspects of fungus and host relationship. Aust. For. Res. 3:27-32.

Stanoz, G.R., D.R. Smith, M.A. Guthmiller, and J.C. Stanoz. 1997. Persistence of Sphaeropsis sapinea on or in asymptomatic shoots of red and jack pines. Mycologia 89:525-530.

Acknowledgments. The authors sincerely thank Dr. Casey Sclar at Longwood Gardens and Dr. Bruce Steward (formerly at Longwood) and Mr. Ronald Horner at Centre Hills Country Club for their cooperation and the International Society of Arboriculture for funding this research through the 1996 John Z. Duling Grant Program.

The Pennsylvania State University

Department of Plant Pathology

University Park, PA 16802-4507

Corresponding author: Gary W. Moorman 
Résumé. Des pins sylvestres (Pinus sylvestris) sur deux sites ainsi que des cornouillers sur un troisième ont été observés en regard de la mortalité de leurs rameaux du printemps 1996 à l'automne 1998. Certains arbres de chacun des sites ont été élagués pour éliminer les pousses et les branches mortes et ont été par la suite comparés à ceux non élagués. Sur les branches atteintes qui sont mortes, les champignons pathogènes les plus présents chez le pin étaient les Sphaeropsis, et chez le cornouiller les Discula et les Botryosphaeria. Nous en concluons que l'élagage intensif des branches mortes atteintes par ces champignons améliore l'apparence des pins sylvestres et des cornouillers, mais n'élimine pas totalement la maladie des arbres.

Zusammenfassung. Vom Frühling 1996 bis zum Herbst 1998 wurde das Zurücksterben von Zweigen und Ästen bei Föhren an zwei Standorten und bei Hartriegel an eim dritten Standort beobachtet. Einige Bäume an jedem Standort wurden gründlich zurückgeschnitten, um tote Zweige und Äste zu eliminieren. Diese wurden mit ungeschnittenen verglichen. Von den anwesenden Pilzen, die ein
Zurücksterben von Ästen verursachen, war Sphaerropsis bei den Föhren der wichtigste und bei den Hartriegeln Discula und Botryosphaeria. Wir schlossen daraus, das ausgiebiges Zurückschneiden von befallenen Ästen das Überleben von Föhren und Hartriegeln signifikant verbessert, aber daß es nicht die Krankheit total von diesen Bäumen eliminiert.

Resumen. Fueron observados pinos Scots (Pinus sylvestris) en dos localidades y cornejos en una tercera por muerte regresiva de ramas, desde la primavera de 1996 hasta el otoño de 1998. Algunos árboles en cada localidad fueron podados para eliminar brotes y ramas muertas y compararlos con los árboles no podados. De los hongos de las ramas, Sphaeropsis fue el más importante en los pinos y Discula y Botryosphaeria lo fueron en los cornejos. Concluimos que la poda racional de las ramas muertas por hongos mejora significativamente la apariencia de los pinos Scots y los cornejos pero no elimina totalmente la enfermedad de los árboles. 